UDC 539.3

DOI: $10.32326 / 1814-9146-2018-80-4-555-565$

\title{
INVESTIGATION OF WOOD ANISOTROPY UNDER DYNAMIC LOADING*
}

(C) 2018

\author{
Konstantinov A.Yu. ${ }^{1}$, Lomunov A.K. ${ }^{1}$, \\ luzhina T.N. ${ }^{2}$, Gray III G.T. ${ }^{3}$
}

\author{
${ }^{1}$ Research Institute for Mechanics, National Research Lobachevsky State University \\ of Nizhny Novgorod, Nizhny Novgorod, Russian Federation \\ ${ }^{2}$ National Research Lobachevsky State University of Nizhny Novgorod, \\ Nizhny Novgorod, Russian Federation \\ ${ }^{3}$ Los Alamos National Laboratory, Los Alamos, New Mexico, USA
}

lomunov@mech.unn.ru

Received by the Editor 2018/09/26

Wood is widely used as a shock absorbing material in various special layered protective structures, for example in containers for the transportation of hazardous materials and substances including: nuclear waste, defense components, a wide range of toxic substances, etc. For the design of such structures and for modelling their behaviour under dynamic load conditions, models equipped with authentic parameters are required. Since wood is a highly anisotropic material, this effect should be taken into account in numerical simulation using the mathematical relationships of an orthotropic solid. Under conditions of a uniaxial stress state, the behaviour of the three structural wood species is studied: pine, birch and sequoia. To achieve a greater degree of deformation the mode of multicyclic loading of the specimen was used. The stress-strain curves of pine and birch were obtained when the specimens were loaded along and across the fibers. Strength and deformation behavior (including the maximum flow stress) characteristics of the tested wood species were determined. It is shown that the yield strength of the three species of wood along the fibers is almost ten times higher than the strength across the fibers. The ultimate strength across the fibers is significantly higher than along the fibers. The energy absorption of pine and birch was determined to facilitate a comparative evaluation of their damping abilities. It is noted that birch exhibits greater energy absorption than pine both along and across the fiber directions.

Analysis of the effect of the stress state on the strength and deformation properties was also carried out for sequoia. Specimens sectioned as a function of direction and their subsequent loading response were carried out at angles of $0^{\circ}, 30^{\circ}$ and $90^{\circ}$ relative to the fiber direction. Under uniaxial loading conditions, the non-uniformity of the radial expansion of the specimens with different directions relative to the wood grain orientation was evaluated. It was found that lateral confinement strongly affects the stress-strain behavior of the sequoia wood species suppressing cracking along the fibers and thereby suppressing damage evolution and final fracture.

Keywords: wood, anisotropy, effects of confinement, multicyclic loading.

*The investigations were executed with partial financial support by RFBF (grant 18-08-00808). 


\section{Introduction}

Every year a huge number of containers with dangerous, including radioactive, substances of various types, spent nuclear fuel, defense components, etc. are transported all over the world. It is of great importance to ensure safety in the transportation of such substances and materials by air, land, sea, and rail transport. This is to avoid potential risk of damage of the wooden containers in the course of transportation that could lead to risks to human life, as well as harm to the environment as well property. The container design and their construction materials must therefore withstand significant dynamic loads without damaging their contents. Damage may occur when a container falls from an aircraft for example, or other type of accident. Wood of different species can be used as the materials damping dynamic loading. It can mitigate the influence of such intense dynamic effects on containers and their contents. In order to reliably calculate the behavior of containers with similar damping materials, data on their properties subjected to impact loading are needed, in particular, dynamic stress-strain curves [1-3]. While for quasi-static impacts there exist some data on the mechanical properties of individual wood species, however quantitative dynamic properties data for wood species remain insufficient [4-15].

It is known that wood is an anisotropic material. Today wood is considered to be a material whose properties exhibit orthogonal anisotropy. Usually when calculating wooden structures the design scheme of a transversely isotropic material is used. The property of the transversely isotropic material varies along and across the wood fibers.

The purpose of this study is to determine the influence of the texture orientation of the wood specimen on the strength and deformation properties of wood. In addition, the degradation of wood properties subjected to cyclic loads and in the conditions of lateral confinement is investigated as an example of the dynamic mechanical behavior of sequoia.

To assess the degree of anisotropy, detailed studies of pine and birch (the most common representatives of coniferous and hardwood trees), as well as sequoia that can be used as damping materials in layered protective structures were conducted.

\section{Experimental methods and specimens}

The dynamic properties of wood under compression were investigated using the setup [16] that implements the Kolsky technique with a split-Hopkinson pressure bar. The installation consists of a pneumatic loading device (gas gun) with a control system, a set of measuring and registering equipment and measuring bars with diameters of $20 \mathrm{~mm}$ made of D16T alloy steel. These bars are equipped with low-base strain gauges. The amplitude of the incident pulse (proportional to the striker velocity) was changed from $30 \mathrm{MPa}$ to $235 \mathrm{MPa}$. Accordingly, the strain rate could be varied from $300 \mathrm{~s}^{-1}$ to $3000 \mathrm{~s}^{-1}$.

Due to the large difference in the acoustic impedances $\rho C$ of the measuring bars and the wood specimen, the amplitude of the reflected pulse can reach $90 \%$ of the amplitude of the incident wave. In this case, the specimen is exposed to several loading cycles. To reliably record repeated loads during a single experiment, it is necessary to exclude the influence on the loading process in the second and subsequent loading cycles of the pulse transmitted through the specimen and then reflected from the back end of the supporting bar in the form of a tensile wave. For this to be achieved, the length of the supporting bar must be increased compared to the length of the loading bar by as many times as the quantity of loading cycles need to be registered [17]. In this series of experiments, the loading bar had the length of $1.5 \mathrm{~m}$, a supporting bar had $4.5 \mathrm{~m}$, which made it possible to record the main and two additional loading cycles (Fig. 1). Markers on the beams mark 
the beginning and the ends of the pulses (incident, reflected and transmitted) registered under the three-cycle loading of the specimen.

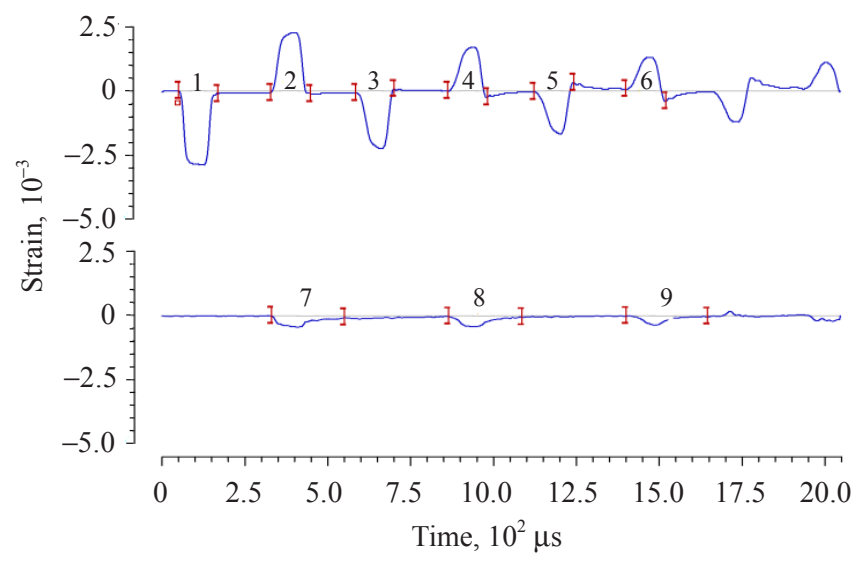

Fig.1. Typical waveform for wood testing

Due to the substantial anisotropy of the wood properties, a uniform (axisymmetric) expansion of the specimen under compression is only possible when loading specimens along the wood fiber direction. When loading the specimen at different angles to the fibers direction, the expansion of the specimen is not uniform or axisymmetric. This effect is particularly evident when loading samples at an angle of $90^{\circ}$ to the fiber direction. In this case, the circular section of the specimen transforms into an ellipsoid shape with the long axis parallel to the fiber direction.

In addition to testing under a uniaxial stress state, some experiments were also performed under a uniaxial strain stress state. This was done to study the influence of the type of stress-strain state on the behavior of the sequoia wood species. Specimens were placed into a rigid jacket to limit their radial expansion. Additional strain gauges were glued to the side surface of the jacket allowed measurement of the radial stress component in the specimen. In combination with traditional measurements by the Kolsky method of longitudinal stress component, it was therefore possible to determine the full stress tensor in the specimen [18-20].

In experiments tested under uniaxial deformation, the degree of anisotropy of the sequoia was estimated by separately measuring the two orthogonal components of the radial stress in the specimen. For this purpose, two independent strain gauges were glued to the side surfaces of the jacket. This allowed the two orthogonal radial components of the stress to be quantified and therefore an estimate of the degree of anisotropy of wood to be determined (Fig. 2).

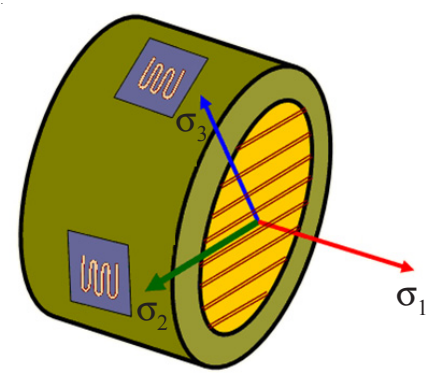

Fig. 2. Separate registration of circumferential deformation of the jacket 
To study the properties of the pine and birch wood species, specimens were fabricated in the form of tablets with a diameter of $\sim 20 \mathrm{~mm}$ and a height of $\sim 10 \mathrm{~mm}$ at different cutting directions relative to the axis of the tree trunk. The angles between the direction of application of the load and the direction of the location of the fibers were $0^{\circ}$ and $90^{\circ}$. The moisture content of the specimens was measured to be $\sim 10 \%$. In addition, specimens of sequoias with a diameter of $\sim 20 \mathrm{~mm}$ and a height of $\sim 10 \mathrm{~mm}$ with cutting angles of $0^{\circ}$, $30^{\circ}$ and $90^{\circ}$ were tested. The humidity of these specimens was $7 \%$.

\section{Results of experiments}

As a result of a series of experiments to investigate pine and birch under loading along and across the fibers, stress-strain diagrams and curves as a function of strain rate were obtained. To assess the degradation of the strength properties, additional loading cycles were recorded in the experiments. When loaded along the fibers, the specimens were observed to display significantly higher strength than when loaded across the fibers and so the magnitude of the reflected wave and, accordingly, the amplitude of the repeated loading wave in the first case (along the fibers) was found to be less than in the second one (across the fibers). This causes a varying degree of strain of the specimens during loading along and across the fibers. In addition, some specimens with a slight degree of damage were reloaded. This made it possible to estimate the damage evolution mechanisms operative up to large values of strain.

The following figures present the stress-strain curves for the pine and birch under loading along and across the fibers. Figures 3 and 4 show graphs for the two regimes in stress amplitude of the loading wave and the corresponding strain rate.

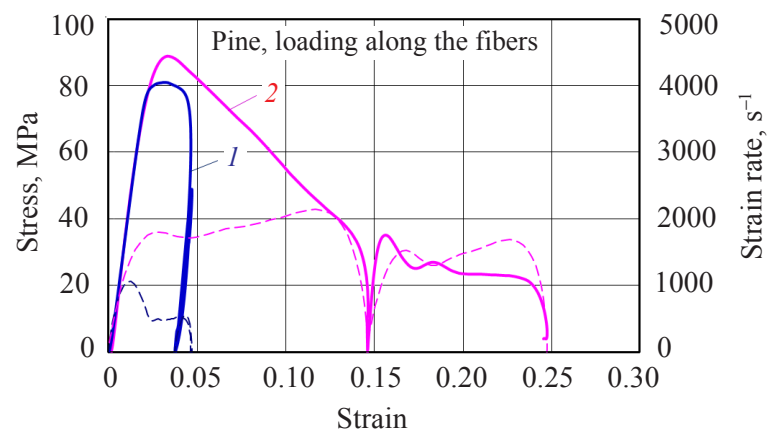

a)

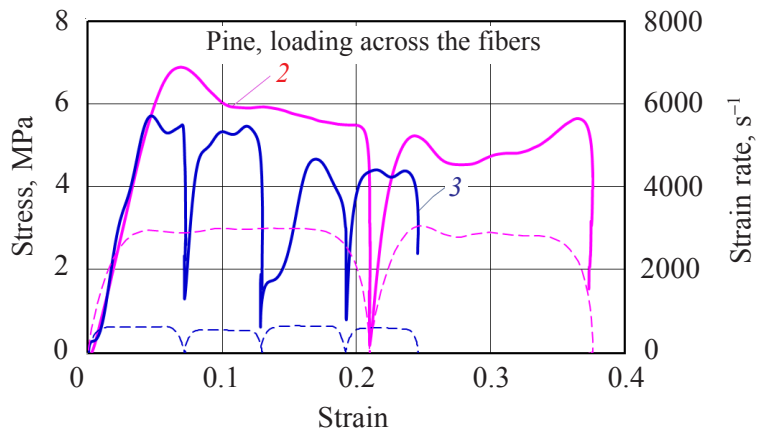

b)

Fig. 3. Typical deformation diagrams of pine under loading along $(a)$ and across $(b)$ fibers: 1 - visible preservation of specimen integrity, 2 - specimen destruction, 3 - severe specimen damage 


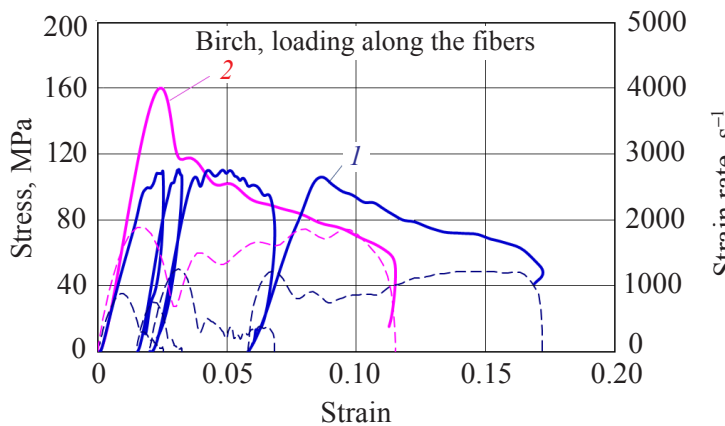

a)

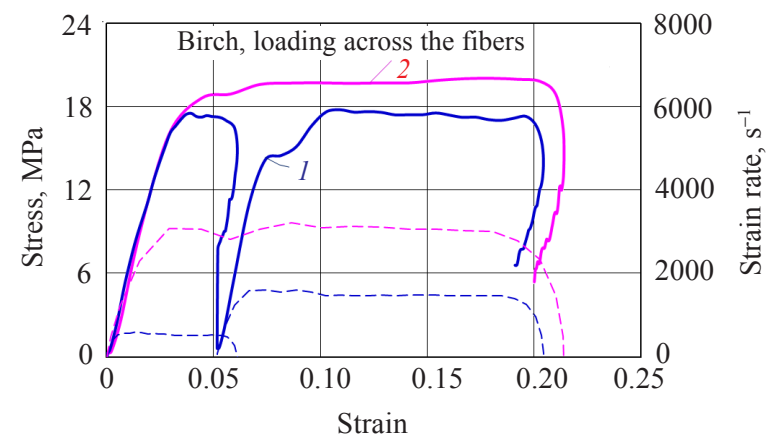

б)

Fig. 4. Typical deformation diagrams of birch under loading along $(a)$ and across $(b)$ fibers: 1 - specimen reloading, 2 - specimen destruction

At a low strain rate, the damage to the specimen was seen to be insignificant, while at a high strain rate the integrity of the specimen was exceeded leading to sample failure. Solid lines in the figures show the stress-strain curves. The dotted lines in the lower parts of the figures are the corresponding curves for the change in the strain rate.

The well-known tendency of a reduction in the strength properties of wood as a function of increasing sectioning angle to the wood grain is well demonstrated in the data presented. The largest values of the module of the loading branches and the failure stress are inherent in the specimens for both wood species with a cutting angle of $0^{\circ}$ to the fiber orientation. The smallest values observed were for specimens with a cutting-out angle of $90^{\circ}$. For small cutting angles, after reaching the limit stress, significant stress relaxation is seen, i.e. a decrease in the bearing ability of the wood is seen for an increase in the degree of deformation. This observation is thought to be potentially caused by microdestruction of the bonds between the wood fibers and the loss of their relative stability. The decrease in the flow stress seen in the stress-strain curves and the non-linear nature of the unloading are both evidence of the damage within the specimens. This is confirmed by their inspection after the tests. For the cutting angle of $90^{\circ}$, the bearing ability of the wood specimens for a significant degree of deformation is not reduced, but on the contrary, the material shows some modest hardening.

For a comparative assessment of the damping capacity, the energy absorption (area under the $\sigma \sim \varepsilon$ curve) of pine and birch was determined (Fig. 5). It is seen that birch has a greater energy absorption than pine, both along and across the fibers. 


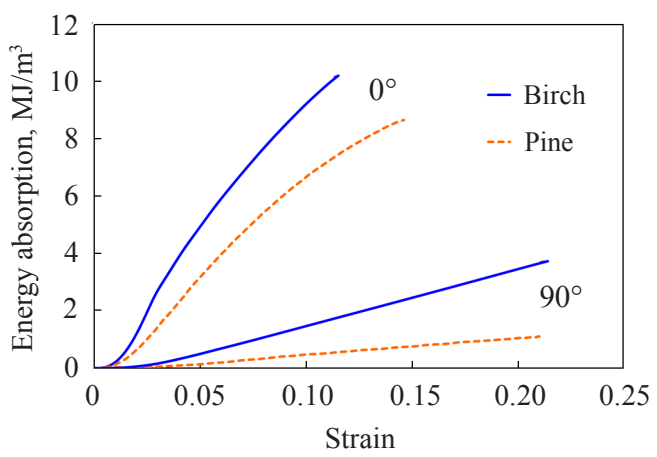

Fig. 5. Energy absorption of pine and birch

The obtained strength properties and energy absorption characteristics for the two woods are given in Table 1. The average modulus for the loading branch for the birch with an angle of $0^{\circ}$ is seen to have the largest value. The breaking stress is also the maximum for this wood.

Strength and damping characteristics of pine and birch

Table 1

\begin{tabular}{|c|c|c|c|}
\hline Cutting angle, degrees & Breaking stress, MPa & Branch load module, MPa & $\begin{array}{c}\text { Energy } \\
\text { absorption, MJ } / \mathrm{m}^{3}\end{array}$ \\
\hline \multicolumn{5}{|c|}{ Pine } \\
\hline 0 & 84 & 3500 & 8.59 \\
\hline 90 & 5.9 & 116 & 1.05 \\
\hline \multicolumn{5}{|c|}{ Birch tree } \\
\hline 0 & 160.7 & 8312 & 9.99 \\
\hline 90 & 16.1 & 447 & 3.36 \\
\hline
\end{tabular}

In addition to pine and birch, specimens of sequoia were investigated jointly with Los-Alamos National Laboratory (LANL) for specimens sectioned at $0^{\circ}, 30^{\circ}$ and $90^{\circ}$ relative to the fiber direction. In the Research Institute of Mechanics at University of Nizhny Novgorod (RIM UNN) specimens were investigated under conditions of both uniaxial stress state and uniaxial strain (specimen in a rigid confining jacket).

The results of static tests for sequoia loaded under uniaxial stress state are shown in Fig. 6. It is clearly seen that the specimens cut at $0^{\circ}$ have the greatest strength and the greatest loading modulus, and the least for specimens cut at $90^{\circ}$.

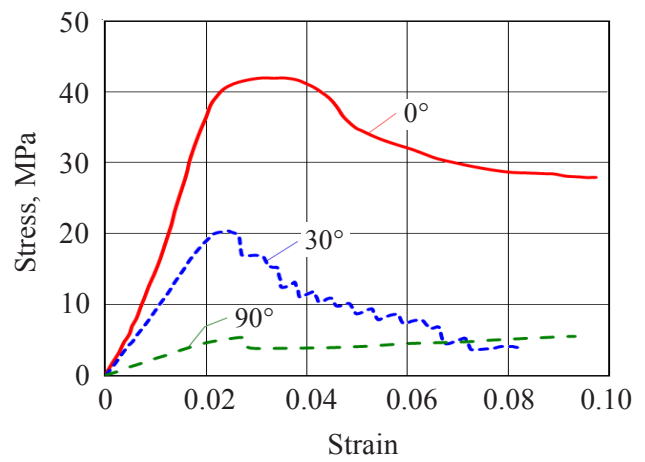

Fig. 6. Static properties of sequoia 
A set of dynamic stress-strain curves was also obtained for samples subjected to multicycle loading. They were obtained for different stress-strain states for sequoia specimens cut at different angles between the loading direction and the wood fiber orientation (Fig. 7). Under uniaxial stress loading, the strength properties of sequoia were found to be higher whereas the deformation behavior is lower under uniaxial strain conditions. The results also show strong anisotropy is displayed by sequoia. These results can be utilized to parametrically identify that wood is an anisotropic material.

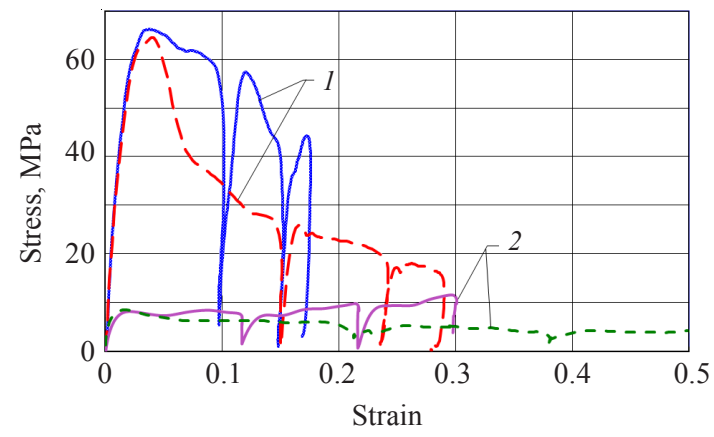

Fig. 7. Behavior of sequoia under uniaxial strain (solid lines) and under uniaxial stress state (dashed lines):

1 - loading along fibers, 2 - loading across fibers

It is interesting to compare the obtained dynamic properties of sequoias with the results of similar tests performed in other laboratory. Figure 8 shows stress-strain curves for samples sectioned at angles of $0^{\circ}, 30^{\circ}$, and $90^{\circ}$ obtained at LANL. Unfortunately in these studies, a higher degree of specimen deformation was not achieved because only single loading of the specimen was performed. Specifically, when loading was conducted along the fibers, the amplitude of the loading wave was insufficient to fail the specimen, therefore, it is impossible to estimate the ultimate strength of the sequoia wood.

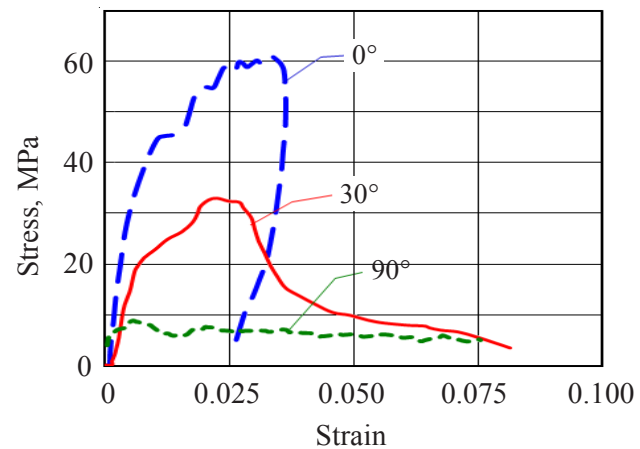

Fig. 8. Sequoia properties at different angles of specimen cutting obtained at LANL

Figure 9 shows quasi-static stress-strain curves for the three cutting-out angles, as well as dynamic curves obtained independently at RIM UNN and LANL. Good coincidence of results between the two testing labs is seen. The undoubted advantage of the results obtained in RIM UNN is a greater degree of deformation achieved due to the use of the multi-cycle loading system. 

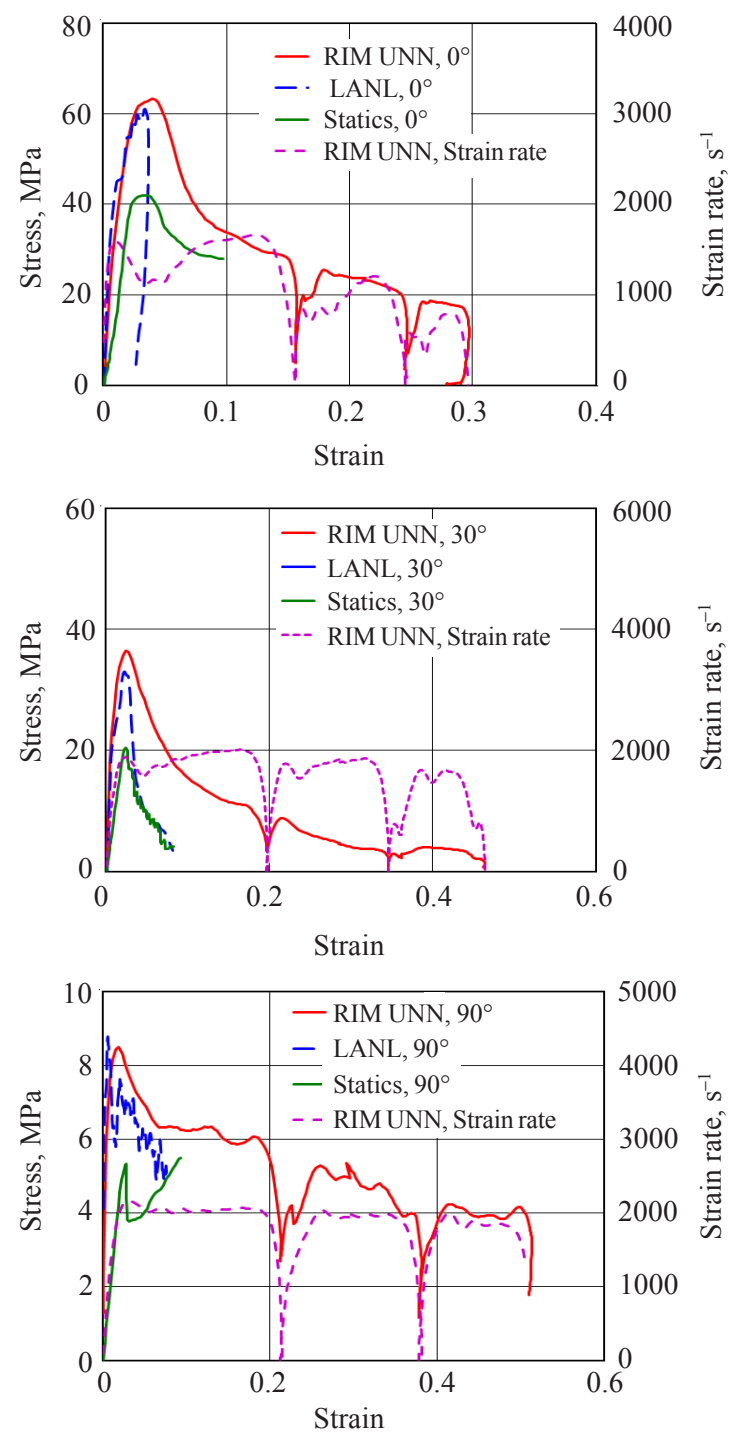

Fig. 9. Static and dynamic properties of sequoia

Two independent strain gauges glued on the side surfaces of the confining jacket (Fig. 2) made it possible to estimate the non-uniformity of the specimen's radial expansion: in one plane the confining sleeve is extended, and in the other plane it is reduced. Accordingly, the components of the radial stress $\sigma_{2}$ and $\sigma_{3}$ in the specimen can have different polarity (Fig. 10). These data should be used in the construction of a complex anisotropic wood model, taking into account the different material behavior, while not only in compression and tension but also in relation to the loading direction to the fibers orientation.

It was found that the lateral confinement strongly affects the stress-strain behavior of sequoia suppressing cracking along the fibers and thereby slowing down the damage evolution leading to failure. Quantitative assessment of the dynamic properties of wood will be used to equip models of wood taking into account its anisotropic properties. Such models are necessary for accurate physically-based predictive engineering numerical modeling and optimization of protective structures using wood as a damping material. 

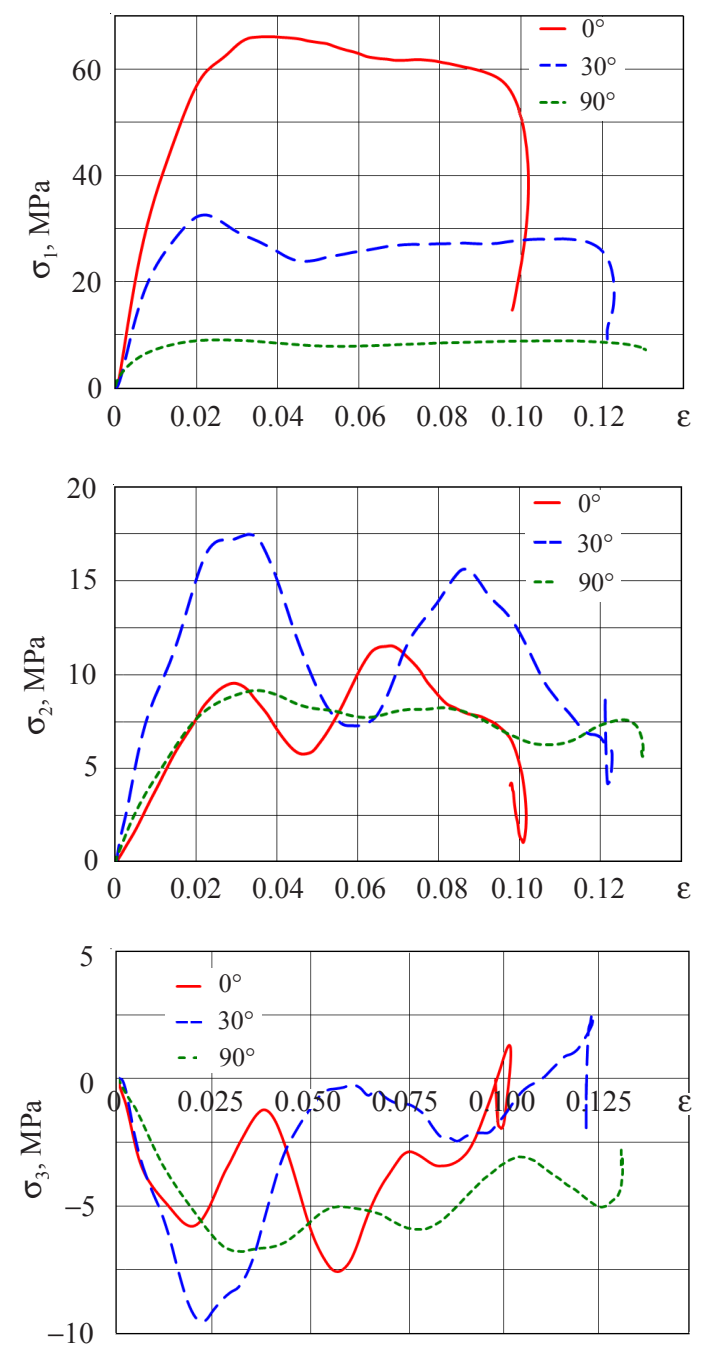

Fig. 10. Anisotropy of sequoia properties under uniaxial deformation

\section{Conclusion}

Studies have shown a significant dependence of the strength and deformation properties of several wood species depending on the sample orientation relative to the wood grain. This orientation dependency must be taken into account when numerically modeling the behavior of wood under dynamic loading. Under conditions of uniaxial deformation, the nonuniformity of the radial expansion of specimens of sequoia as a function of loading directions relative to the wood fibers was estimated. It was found that the lateral confinement strongly affects the stress-strain behavior of sequoia wood suppressing cracking along the fibers and thereby slowing damage evolution leading to fracture. These data should be used in the derivation of complex wood models, taking into account the different material behavior as a function of the inherent anisotropy in wood, while not only in compression and tension, but also in relation to the loading direction to the fiber orientation. 
References

. Evaluation of LS-DYNA. Wood Material Model 143. Publication No. FHWA-HRT-04-096. 2005.

2. Manual for LS-DYNA. Wood Material Model 143. Publication No. FHWA-HRT-04-097. 2007.

3. Zhao S., Zhao J.X., Han G.Z. Advances in the study of mechanical properties and constitutive law in the field of wood research. IOP Conf. Series: Materials Science and Engineering. 2016. Vol. 137. No 1. P. 1-9.

4. Johnson W. Historical and present-day references concerning impact on wood. Int. J. Impact Eng. 1986. Vol. 4. P. 161-174.

5. Reid S.R., Peng C., Reddy T.Y. Dynamic uniaxial crushing and penetration of wood, In: Mechanical Properties of Materials at High Rates of Strain. J. Harding, ed. Inst. Phys. Conf. Series. 1989. No 102. Bristol. P. 535-542.

6. Reid S.R., Reddy T.Y., Peng C. Dynamic compression of cellular structures and materials. In: Structural Crashworthiness and Failure. New York. Elsevier Applied Science Publishers. 1993. P. 295-340.

7. Reid S.R., Peng C. Dynamic uniaxial crushing of wood. Int. J. Imp. Eng. 1997. Vol. 19. No 5-6. P. 531-570.

8. Buchar J., Krivanek I., Severa L. High rate behaviour of wood. New Experimental Methods in Material Dynamics and Impact. Trends in Mechanics of Materials. Eds. W.K. Nowacki, J.R. Klepaczko. Warsaw. 2001. P. 357-362.

9. Harrigan J.J., Reid S.R., Tan P.J., Reddy T.Y. High rate crushing of wood along the grain. Int. J. Mech. Sci. 2005. Vol. 47. No 4-5. P. 521-544.

10. Wouts J., Haugou G., Oudjene M., Coutellier D., Morvan H. Strain rate effects on the compressive response of wood and energy absorption capabilities. Part A: Experimental investigations. Composite Structures. 2016. Vol. 149. P. 315-328.

11. Bragov A.M., Lomunov A.K. Dynamic properties of some wood species. J. Phys. IV France 7 Colloque 3. 1997. P. 487-492.

12. Bol'shakov A.P., Gerdyukov N.N., Novikov S.A. et al. Damping properties of sequoia, birch, pine, and aspen under shock loading. J. Appl. Mech. Tech. Phys. 2001. Vol. 42. No 2. P. 202-210.

13. Allazadeh M.R., Wosu S.N. High strain rate compressive tests on wood. Strain. 2011. Vol. 48. No 2. P. 101-107.

14. Holmgren S.-E., Svensson B.A., Gradin P.A., Lundberg B. An encapsulated split Hopkinson pressure bar for testing of wood at elevated strain rate, temperature, and pressure. Experimental Techniques. 2008. Vol. 32. P. 44-50.

15. Брагов А.М., Ломунов А.К., Сергеичев И.В., Грей III Дж.Т. Влияние скорости деформации, температуры и угла вырезки на механические свойства некоторых пород древесины. Экстремальные состояния вещества. Детонация. Ударные волны. Тр. международ. конф. ІХ Харитоновские тематические научные чтения. Саров, РФЯЦ - ВНИИЭФ, 12-16 марта 2007. С. 349-353.

Bragov A.M., Lomunov A.K., Sergeichev I.V., Gray III G.T. The effect of strain rate, temperature and cutting angle on the mechanical properties of certain wood species. Extreme States of Matter. Detonation. Shock Waves: Proceedings of the International Conference IX Khariton's Thematic Scientific Readings. Sarov. RFNC-VNIIEF. March 12-16. 2007. P. 349-353 (In Russian).

16. Bragov A.M., Lomunov A.K. Methodological aspects of studying dynamic material properties using the Kolsky method. Int. J. Impact Eng. 1995. Vol. 16. No 2. P. 321-330.

17. Bragov A.M., Lomunov A.K., Sergeichev I.V. Modification of the Kolsky method to study the properties of low-density materials under high-speed cyclic deformation. J. Appl. Mech. Tech. Phys. 2001. Vol. 42. No 6. P. 199-204.

18. Bragov A.M., Grushevsky G.M., Lomunov A.K. Use of the Kolsky method for studying shear resistance of soils. DYMAT J. 1994. Vol. 1. No 4. P. 253-259.

19. Bragov A.M., Lomunov A.K., Sergeichev I.V., Tsembelis K., Proud W.G. Determination of physicomechanical properties of soft soils from medium to high strain rates. Int. J. Impact Eng. 2008. Vol. 35. No 9. P. 967-976. 
20. Брагов А.М., Ломунов А.К., Константинов А.Ю., Ламзин Д.А., Баландин Вл.Вл. Оценка радиальной деформации образца на основе теоретико-экспериментального анализа методики динамических испытаний материалов в жесткой обойме. Проблемы прочности и пластичности. 2016. Т. 78. №4. С. 378-387.

Bragov A.M., Lomunov A.K., Konstantinov A.Yu., Lamzin D.A., Balandin V1.Vl. Estimation of the radial deformation of the specimen based on the theoretical and experimental analysis of the method of dynamic testing of materials in a rigid holder. Problems of Strength and Plasticity. 2016. Vol. 78. No 4. P. 378-387 (In Russian).

\title{
ИССЛЕДОВАНИЕ АНИЗОТРОПИИ ДРЕВЕСИНЫ ПРИ ДИНАМИЧЕСКОМ НАГРУЖЕНИИ*
}

\author{
Константинов А.Ю. ${ }^{1}$, Ломунов А.К. ${ }^{1}$, Южина Т.Н. ${ }^{2}$, Грей III Дж.Т. ${ }^{3}$ \\ ${ }^{1}$ Научно-исследовательский институт механики Национального исследовательского \\ Нижегородского государственного университета им. Н.И. Лобачевского, \\ Нижний Новгород, Российская Федераичия \\ ${ }^{2}$ Национальный исследовательский Нижегородский государственный университет \\ им. Н.И. Лобачевского, Нижний Новгород, Российская Федерация \\ $3^{3}$ Лос-Аламосская национальная лаборатория, Лос-Аламос, Нью-Мексико, США
}

Древесина широко используется в качестве материала, амортизирующего ударное воздействие в различных специальных слоистых защитных конструкциях, например в контейнерах для транспортирования опасных веществ: отходов ядерной энергетики, компонентов ядерных вооружений, широкого круга токсичных веществ и т.д. Для проектирования таких конструкций и моделирования их поведения в условиях динамической нагрузки необходимы модели, оснащенные аутентичными параметрами. Поскольку древесина является сильно анизотропным материалом, этот эффект следует учитывать при численном моделировании с использованием математических соотношений ортотропного твердого тела. В условиях одноосного напряженного состояния исследовано поведение трех конструкционных пород древесины: сосны, березы и секвойи - при высоких скоростях деформации. Для достижения большей степени деформации использовался режим многоциклового нагружения образца. Получены диаграммы деформирования сосны и березы при нагружении вдоль и поперек волокон. Определены прочностные и деформационные (в том числе предельные) характеристики испытанных пород древесины. Показано, что прочность древесины вдоль волокон примерно в 10 раз выше, чем прочность поперек волокон. Предельные деформации поперек волокон существенно выше, чем вдоль волокон. Для сравнительной оценки демпфирующей способности была определена энергоемкость сосны и березы. Отмечено, что береза обладает бо́льшим энергопоглощением, чем сосна, причем как вдоль, так и поперек волокон.

Для секвойи проведен анализ влияния вида напряженно-деформированного состояния на прочностные и деформационные свойства. Вырезка образцов и последующее нагружение были проведены под углами 0,30 и $90^{\circ}$ к направлению волокон. В условиях одноосной деформации оценена неравномерность радиального расширения образцов с различным направлением вырезки относительно волокон. Обнаружено, что боковое ограничение сильно влияет на напряженно-деформированное поведение секвойи, подавляя трещины вдоль волокон и тем самым замедляя разрушение.

Ключевые слова: древесина, анизотропия, испытание в обойме, многоцикловое нагружение.

* Выполнено при частичной финансовой поддержке РФФИ (грант №18-08-00808). 